\title{
Design and Simulation of Stand-Alone DC Grid for Commercial Buildings
}

\author{
Vijayalaxmi T Chetti \\ M.Tech $4^{\text {Th }}$ Sem \\ Rajiv Gandhi Institute of Technology \\ Bangalore, Karnataka, India \\ Priyanka.G \\ Assistant Professor, Dept. of EEE \\ Rajiv Gandhi Institute of Technology \\ Bangalore, Karnataka, India
}

\begin{abstract}
In the Present world AC is used for its better transmitting capability but there is much of power conversion from AC to DC and vice versa has to be done. This increases utilization of devices such as rectifiers (AC to DC) and inverters (DC to $\mathrm{AC}$ ). Thus demanding for more cost investment and also results in much of power losses. Since the most of electric appliances use DC power, it makes a practical proposal to study the usage of DC. Most of the renewable energy source such as solar, wind (motor) and fuel cell energy systems produce DC energy. It is practical to think of using DC. Thus conversion losses and investment can be reduced. By making the cluster of renewable energy sources and using it in the same location (not transmitting too far distances), DC can be used efficiently. In this project design of de grid is made and simulated by using MATLAB software to conclude the practicality of using DC power by using renewable energy resources.
\end{abstract}

Keywords - DC grid, PV, Wind, Fuel cell, Bi-directional converter, Power flow control, MATLAB Simulink

\section{INTRODUCTION}

The electricity requirement is increasing every year. Due to this increase in requirement. It is unable to fulfil the electric requirement of every one. It enables us to think on the alternative energy resources. There are some energy resources which produce carbon dioxide which is spoiling earth's atmosphere too. Thus there is requirement to produce the energy without carb dioxide and also which can satisfy yearly energy requirement.

It is also very important aspect to concentrate losses in power station. Some of the power is lost while transferring the power from one location to other lotion by conductor cables. This can be overcome by making smaller grids and transmitting power locally rather than transmitting long distance. Even there are losses pertaining to the conversion of the power between $\mathrm{AC}$ and DC. This is also great area of concentration to reduce the power conversion losses.

Most of the electrical Products use DC such as, computers, telephones, televisions, coffee makers, etc. Motors for applications such as refrigeration, ventilation or pumping etc. But in real world $\mathrm{AC}$ is converted into DC by using rectifiers as converters, the outcome after rectifiers is connected to the devices for its applications

Most of the renewable resources such as PV, Fuel cell and energy storage systems provide DC and its energy is converted to $\mathrm{AC}$ and used. While converting from $\mathrm{DC}$ to $\mathrm{AC}$ and using it for the applications energy undergoes lot of losses

By avoiding these conversions the losses can be minimized and energy can be supplied at cheaper rates. This can be done by making a DC grid and using the same DC for the application without any type of conversion.

\section{II.METHODOLOGY}

The above fig shows the standalone de grid for commercial building. This de grid can be used to produce electricity and supply the same to the remote locations where transmitting the power from hydropower plants (AC mains) is difficult. In this project we have used 3 sources such as solar, wind and fuel cell to generate the power and to ensure continuous supply. A battery is connected to bi-directional DC/DC to allow proper charging and discharging processes. The battery is integrated to the system to ensure the power supply in case of energy crises. A solar PV system generates power and is connected to low voltage bus $48 \mathrm{Vdc}$. Wind and fuel cell generates the power required for the high voltage devices at $380 \mathrm{Vdc}$. A bidirectional DC-DC converter is used as interface between $380 \mathrm{Vdc}$ and 
48Vdc. To ensure reliable operation of the entire system, the two DC buses are linked by a bi-directional DC/DC converter. The two DC buses have to supplement each other in terms of power. The power flow control module will ensure that all the loads will receive the required power irrespective of the power generation status of the buses. At $48 \mathrm{vdc}$ bus the losses comparison is done between $\mathrm{AC}$ and $\mathrm{DC}$ load. We have provided 2 buses in the system and divided high power loads and low power loads respectively. The low power loads are connected to 48VDC and high power loads are connected to $380 \mathrm{VDC}$. Thus bucking of power in the grid is reduced and also efficiency of the system is increased.

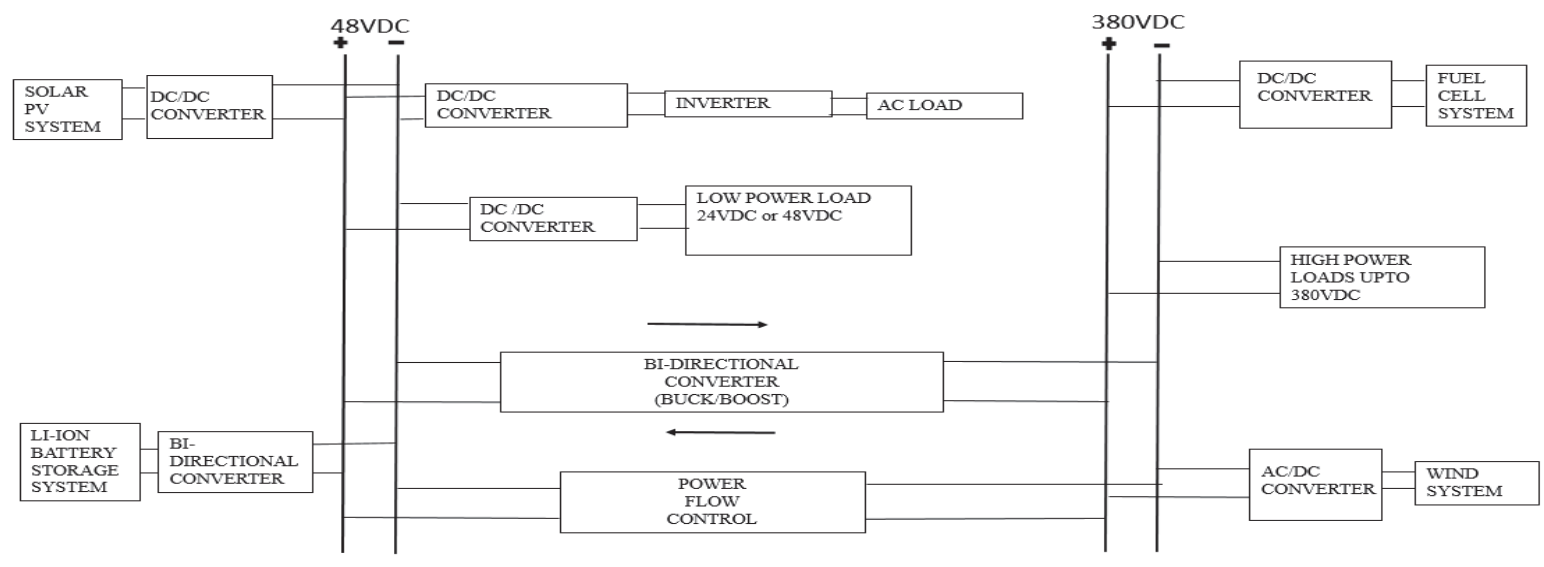

Fig. 1 Block diagram of proposed study

LOAD CONSIDERED FOR DC COMMERCIAL BUILDING

\begin{tabular}{|c|c|c|c|c|}
\hline S/no & APPLIANCES & QTY & TOTAL POWER (W) & $\begin{array}{l}\text { INDIVIDUAL } \\
\text { CURRENT } \\
\text { (A) }\end{array}$ \\
\hline & $\begin{array}{l}\text { LOW } \\
\text { POWER(24Vdc) }\end{array}$ & & & \\
\hline 1 & LCD TV & 01 & $213 w$ & 8.87 \\
\hline 2 & Desktop computer & 07 & $40 \mathrm{~W} / \mathrm{each}=280 \mathrm{w}$ & 11.6 \\
\hline 3 & Laptops & 05 & $40 \mathrm{~W} / \mathrm{each}=200 \mathrm{w}$ & 8.33 \\
\hline 4 & Lighting LED & 16 & $18 \mathrm{~W} / \mathrm{each}=300 \mathrm{w}$ & 12.5 \\
\hline 5 & Wireless router & 01 & $7 \mathrm{~W}$ & 0.29 \\
\hline \multirow[t]{3}{*}{6} & Cellphone charger & 10 & $1 \mathrm{~W} /$ each $=10 \mathrm{w}$ & 0.41 \\
\hline & Total power & & $1010 W$ & \\
\hline & $\begin{array}{l}\text { HIGH } \\
\text { POWER(3SOVdc) }\end{array}$ & & & \\
\hline 7 & Air conditioner & 04 & $1500 \mathrm{~W} / \mathrm{each}=6000 \mathrm{~W}$ & 15.78 \\
\hline 8 & Coffee maker & 01 & $1500 \mathrm{~W}$ & 3.94 \\
\hline \multirow[t]{2}{*}{9} & Refrigerator & 01 & $800 \mathrm{~W}$ & 2.10 \\
\hline & Total power & & $8300 \mathrm{~W}$ & \\
\hline
\end{tabular}

Table: 1 Appliances voltage and current requirement for DC commercial building [4], [5], [6]

\section{A.POWER FLOW SPECIFICATIONS}

To ensure that the power flow within the system is balanced, the following assumptions will be made [7]

1. Total power to be available at all times at both the 48 VDC and 380 VDC buses should be $9 \mathrm{~kW}$.

2. The two buses will supplement each other to meet the power requirements for each bus. This means that if the power generating units of one of the buses cannot generate a total required power to furnish the load, the other bus will transfer the remaining balance of the power via the bi-directional DC-DC converter. 
3. The power flow magnitude and direction via the bidirectional DC-DC converter will depend on the power status of the both the DC buses.

4. Maximum power to be flowing in either direction of the buses via the bi-directional converter at one point in time should not exceed required power.

5. Constant hydrogen will be supplied to the fuel cell stacks and thus the fuel cell system will continuously supply the rated power.

\section{B.STORAGE SYSTEM SIZING}

A battery will be used as the storage device. Batteries find application that require evening out mismatches between solar energy harvesting and demand. The lithium ion battery is to be used as the storage device due to the high recommendations it has despite the cost associated with it.

The battery is supposed to supply $1 \mathrm{~kW}$ for $8 \mathrm{hrs:}$

$\mathrm{kWhr} \_$required $=(1)(8)=8 \mathrm{kWh}=8000 \mathrm{Wh}$

In order to prolong the service life of the battery bank, a Depth of Discharge (DOD) of $50 \%$ will be used. De-rating using the DOD selected:

Derated_kWh $=8000 / 0.5=16000 \mathrm{Wh}$

Assuming the battery pack will be located close to the bidirectional DC-DC converter, we can say that it will be subjected to ambient temperatures of $60^{\circ} \mathrm{C}$ due to heat generated by loss mechanism within the converter. A temperature of $60^{\circ} \mathrm{C}$ will correspond to a de-rating factor of 1.11 .

De-rating the battering bank at $60^{\circ} \mathrm{C}=16000 \times 1.1=17600 \mathrm{Wh}$

A standard $48 \mathrm{~V}$ voltage was chosen for the battery bank (two $48 \mathrm{v}$ batteries connected in series)

Obtaining the rating of the battery bank:

Rating $=17600 / 96=183 \mathrm{Ah}$

But in this project the capacity of battery $48 \mathrm{~V}, 187 \mathrm{Ah}$ is used

C. PV SYSTEM SIZING

The assumption made is that the PV system is to generate $1 \mathrm{~kW}$ per hour during favorable insolation periods.

Total $\mathrm{kW}=1 \mathrm{kWh}$

To account for losses with the PV systems, we have to calculating a de-rating factor based on these facts:

- $15 \%$ for temperatures above $25 \%$

- $5 \%$ for losses due to rays not striking the panel

- $10 \%$ for losses due to the absence of MPPT features

- $5 \%$ in case of dust/particles on the panel surface

- $10 \%$ allowance for panel below specific age.

- Total de-rating factor for losses $=0.85 * 0.95 * 0.90 * 0.95 * 0.90 *=0.62$

- In India, solar radiation levels usually vary between $4-7 \mathrm{kwh} / \mathrm{m} 2$

- The design will be done using the worst case insolation levels of $4 \mathrm{kwh} / / \mathrm{m} 2$

- Obtaining the panel generation factor:

- Panel generation factor $=0.62 * 4=2.48$

- $\quad$ Total Wp of PV panel capacity needed, $\mathrm{Wp}=1000 / 2.48=403 \mathrm{~W}$

The Monocrystalline SW 115 MONO module manufactured by sun electronics will be used for the panels, Ratings of the panel are shown in the table below:

\begin{tabular}{|l|l|}
\hline Max.power(Pmmp) & $115 \mathrm{~W}$ \\
\hline Max.voltage(Vmpp) & $16.7 \mathrm{~V}$ \\
\hline Max. current(Impp) & $6.89 \mathrm{~A}$ \\
\hline Open circuit voltage(Voc) & $21.0 \mathrm{~V}$ \\
\hline Short circuit current (Isc) & $7.65 \mathrm{~A}$ \\
\hline
\end{tabular}

Table: 3 Ratings of SW $115 \mathrm{~W}$ MONO panel

- $\quad$ Number of panels $=403 / 115=3.5 \approx \mathbf{4}$ panels 
- Connecting the 4 panels in a series will produce the following ratings:

- Voltage $\mathrm{a} / \mathrm{c}$ the series string $=4 * 16.7=\mathbf{6 6 . 8 V}$

- $\quad$ Total power generated by the series string $=66.8 * 6.89=\mathbf{4 6 0 . 2 5} \mathrm{W}$

- By connecting 2 strings in parallel with result in a total capacity of,

- $\mathrm{Wp}=2 * 460.25=\mathbf{9 2 0 . 5 0 4 W}<\mathbf{1 k W}$

- By connecting 3 strings in parallel with result in a total capacity of,

- $\mathrm{Wp}=3 * 460.25=\mathbf{1 3 8 0 . 7 5}>\mathbf{1 k W}$

To ensure that the PV system generates at least $1 \mathrm{~kW}, 3$ strings in parallel will be used to realize the solar array.

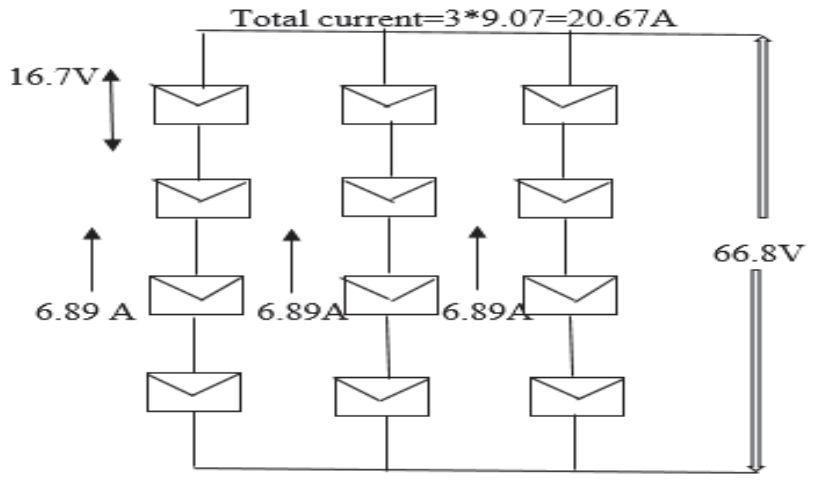

Fig.2 Solar panel array for the PV system

Total 12 panels will used to realize the solar PV array

\section{D.WIND SYSTEM}

The design of wind power system is basically depend on wind turbine, controls, and generation system and foundation design. Wind turbine is a device that converts rotational mechanical energy in to electric energy. The power output of the wind power is considers the design of many parts in the wind turbine such as design of blades, rotor, stator and hub and also it depends on which type of wind turbine is used either horizontal or vertical wind turbine etc.

The UE 42 Plus module manufactured by Unitron Energy will be used for the wind,

\begin{tabular}{|l|l|}
\hline Model & UE 42 Plus \\
\hline Rated output & $5.1 \mathrm{~kW}$ \\
\hline Rated wind speed & $11 / 25$ \\
\hline Peak output & $5600 \mathrm{~W}$ \\
\hline Cut-in wind speed $\mathrm{m} / \mathrm{s}$ & $2.7 / 6$ \\
\hline Generator & Permanent magnet synchronous generator \\
\hline Insulation class & Class' $\mathrm{H}^{\prime}$ \\
\hline Efficiency & $>87 \%$ \\
\hline Poles & 16 \\
\hline Rpm-50 Hz/60Hz & $375 / 450$ \\
\hline Rotor diameter & $5.04 \mathrm{~m} 2$ \\
\hline No of blades & 3 \\
\hline Blade material and $\mathrm{Cp}$ & Carbon fibre composite, 0.37 \\
\hline Swept area & $21.4 / 230$ sq $/$ sq.ft \\
\hline Tip speed ratio(TSR) & 8.5 \\
\hline APPLICATIONS & Stand-alone, Grid connection, \\
\hline
\end{tabular}

Table: 4 Wind turbine specifications 


\section{E.FUEL CELL}

The design of fuel cell is based on the required output. The fuel cells are stacked in series as the power required increases.

For the Fuel Cell system design, the PEM fuel cell will e used based on its associated advantages. The module H4000 PEM manufactured by QUINTECH will be used for the fuel cell system.

\begin{tabular}{|l|l|}
\hline Module & H-4000 PEM FC \\
\hline No of cells & 96 \\
\hline Rated power & 4000 \\
\hline H2 supply value voltage & $12 \mathrm{~V}$ \\
\hline Blower voltage & $12 \mathrm{~V}$ \\
\hline Reactants & Hydrogen and Air \\
\hline External temp & $5-30^{\circ} \mathrm{C}$ \\
\hline Max. stack temp & $65^{\circ} \mathrm{C}$ \\
\hline H2 pressure & $7,2-9,4$ PSI \\
\hline Humidification & Self humidification \\
\hline Cooling & Air(Integrated cooling fa) \\
\hline Weight(with fan and casing) & $14 \mathrm{~kg}$ \\
\hline Dimensions with fan & $380^{*} 160^{*} 360 \mathrm{~mm}$ \\
\hline Flow rate at rated output & $58^{\prime} \mathrm{L} /$ min \\
\hline Start-up time & Immediate \\
\hline Efficiency of stack & $55^{2} \%$ at $57.6 \mathrm{~V}$ \\
\hline
\end{tabular}

Table: 5 H-4000 PEM fuel cell specifications

\section{F. DC LINK BI-DIRECTIONAL CONVERTER}

For the DC bus link, a bi-directional buck boost was used to interface the two DC buses together. Table. 6 shows the input design parameters of the converter.

\begin{tabular}{|l|l|}
\hline VHIG & $380 \mathrm{VDC}$ \\
\hline VIOW & $48 \mathrm{VDC}$ \\
\hline Freq & $10 \mathrm{KHz}$ \\
\hline BUCK MODE & \\
\hline D & 0.126 \\
\hline IL & $187.5 \mathrm{~A}$ \\
\hline R & $0.2560 \mathrm{hm}$ \\
\hline L & $11 \mathrm{e}-06 \mathrm{H}$ \\
\hline C & $993 \mathrm{e}-06 \mathrm{~F}$ \\
\hline POUT & $9 \mathrm{~K}$ \\
\hline BOOST MODE & \\
\hline D & 0.87 \\
\hline IL & $23.68 \mathrm{~A}$ \\
\hline R & $16.040 \mathrm{hm}$ \\
\hline L & $11 \mathrm{e}-06 \mathrm{H}$ \\
\hline C & $10.84 \mathrm{~F}-06 \mathrm{~F}$ \\
\hline
\end{tabular}

Table: 6 Input parameters for the DC link

\section{G. POWER FLOW CONTROL}




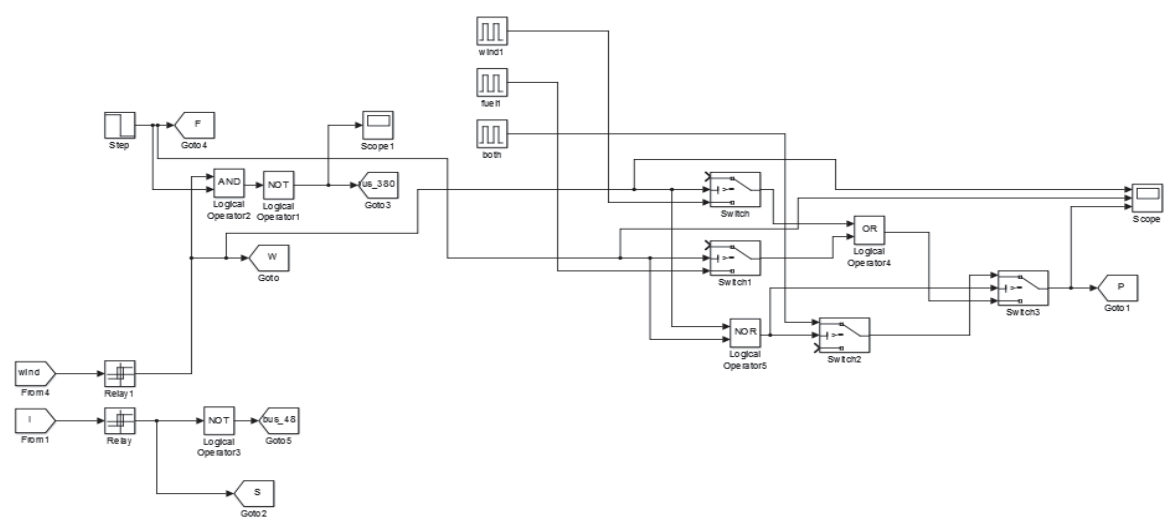

Fig.3 matlab simulation of power flow controll block

POWER FLOW CONTROL WORKING SCENARIO

\begin{tabular}{|l|l|l|l|l|l|l|}
\hline TIME & $0-0.5 \mathrm{sec}$ & $1 \mathrm{sec}$ & $2 \mathrm{sec}$ & $2.5 \mathrm{sec}$ & $3 \mathrm{sec}$ & $4 \mathrm{sec}$ \\
\hline Solar & ON & OFF & ON & ON & ON & OFF \\
\hline Wind & ON & OFF & OFF & OFF & ON & OFF \\
\hline Fuel cell & ON & ON & ON & OFF & OFF & OFF \\
\hline Battery & ON & ON & ON & ON & ON & ON \\
\hline
\end{tabular}

Table: 7 Power flow control working scenario

\section{IV.SIMULATION MODEL AND RESULTS}

The stand-alone de grid for commercial buildings is simulated using MATLAB Simulink and Simulink diagram and waveforms are shown in Fig.4and 5

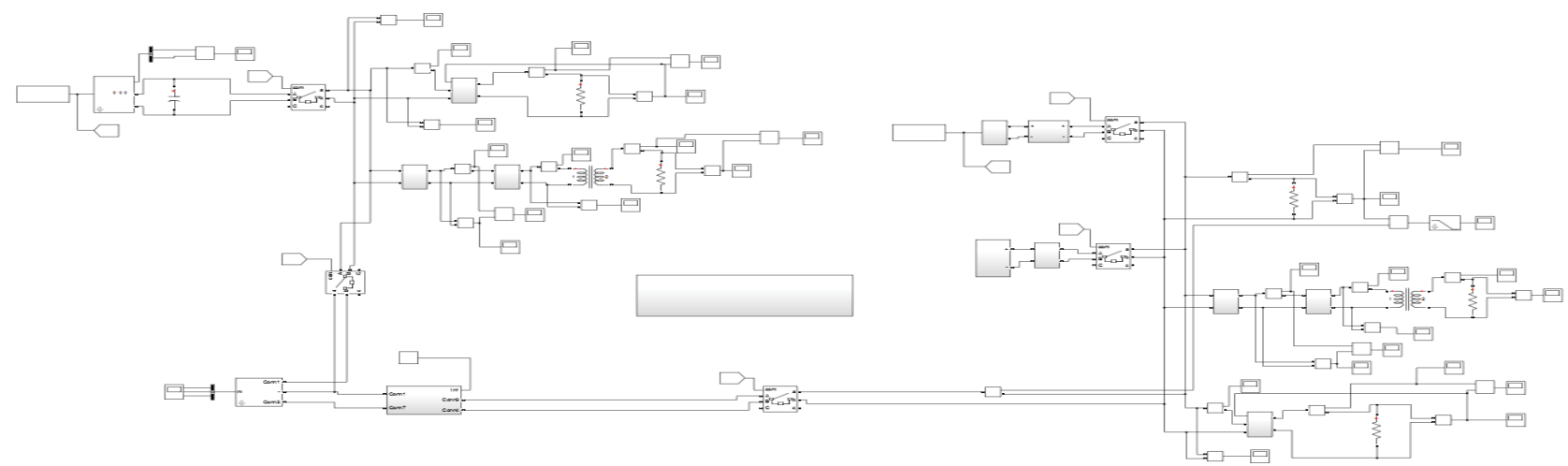

Fig.4 MATLAB simulation of stand-alone de grid for commercial buildings

\section{RESULTS}




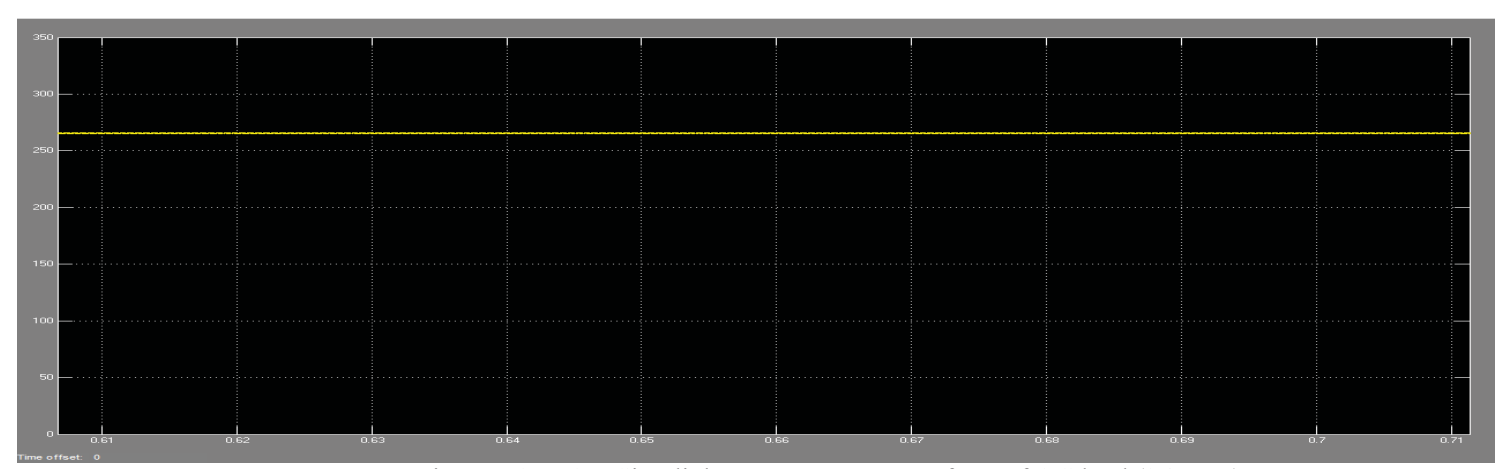

Fig. 7 MATLAB-Simulink output power wave form of AC load (265.5W)

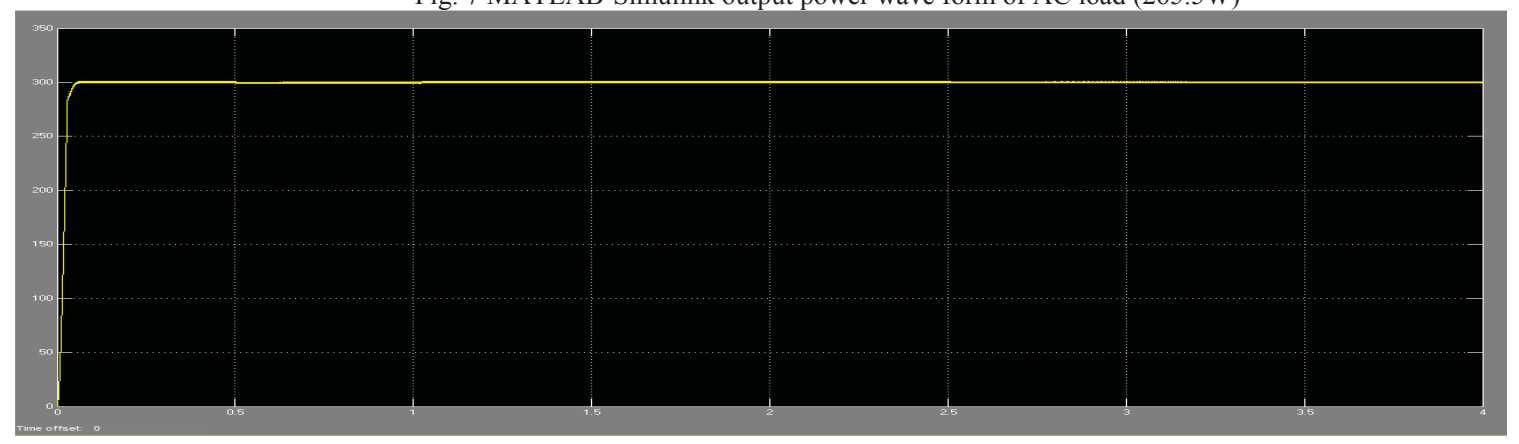

Fig. 10 MATLAB-Simulink output power wave form of DC load (300W)

\section{VI.RESULTS AND DISCUSSION}

Figures 7 and 10 shows the waveforms of power losses in AC and DC loads. From theses waveforms it is shown that the losses in AC load is more than that of DC load.

POWER CALCULATION

$A C L O A D$

\begin{tabular}{|l|l|l|}
\hline COMPONENTS & OUTPUT & VALUES \\
\hline \multirow{4}{*}{ DC/DC Buck converter } & Voltage & $24 \mathrm{~V}$ \\
\cline { 2 - 3 } & Current & $15 \mathrm{~A}$ \\
\cline { 2 - 3 } & Power & $362 \mathrm{~W}$ \\
\hline \multirow{3}{*}{ Inverter } & Voltage & $24 \mathrm{~V}$ \\
\cline { 2 - 3 } & Current & $14.6 \mathrm{~A}$ \\
\cline { 2 - 3 } & Power & $350.4 \mathrm{~W}$ \\
\hline Transformer & Voltage & $216 \mathrm{~V}$ \\
\cline { 2 - 3 } & Current & $1.23 \mathrm{~A}$ \\
\cline { 2 - 3 } & Power & $265.6 \mathrm{~W}$ \\
\hline
\end{tabular}

DC LOAD 


\begin{tabular}{|l|l|l|}
\hline COMPONENT & OUTPUT & VALUES \\
\hline \multirow{4}{*}{ DC/DC Buck converter } & Voltage & $24 \mathrm{~V}$ \\
\cline { 2 - 3 } & Current & $12.5 \mathrm{~A}$ \\
\cline { 2 - 3 } & Power & $300 \mathrm{~W}$ \\
\hline
\end{tabular}

Table: 8 Power comparison table

\section{CONCLUSION}

The cluster type of DC grid is simulated in MATLAB software to understand its practical application. By adding four sources solar, wind, fuel cell and battery, the required output can be drawn for the usage. The DC grid has high efficiency compared to the AC grid as there are conversions to be made in AC grids. This is shown by the physical model in which the DC output is $16 \%$ efficient than the AC output. Further reduction losses in the DC grid is made by adding 2 buses. By using 2 buses one for low voltage and other for high voltage the bucking is minimized. Hence the improvement in the efficiency can be observed.

\section{REFERENCES}

[1] Ott, L: Han, Y:"Voltage control and stabilization of a distributed and a centralized DC micro grid"2015 IEEE

[2] K. Rykov, L. Ott "Modelling of Aggregated Operation of Power Modules.pdf" 2014 IEEE

[3] Victor-Juan Webb "Design of a 380 V/24 V DC Micro-Grid for Residential DC Distribution", 2013

[4] "Home Appliance Energy Use," GE, 2012.

[5] "Typical Energy Costs for Electric Household Appliances," Suwannee Valley Electric Cooperative, Inc., 2010.

[6] "Online Power Usage," Consumer Power, Inc., 2012.

[7] Itai Geavas Hamunakwadi, "Design of a Hybrid Power System for a Low DC Voltage Distribution system suitable for remote areas" 2014 IEEE 